\author{
Д. С. Христенко
}

Інститут рибного господарства УААН

\title{
МОРФОМЕТРИЧНІ ПОКАЗНИКИ ЛЯЩА (ABRAMIS BRAMA) КРЕМЕНЧУЦЬКОГО ВОДОСХОВИЩА
}

Показано довгострокову результуючу дію комплексу факторів, що склалися у Кременчуцькому водосховищі, на морфометричні показники ляща (Abramis brama L.). На зазначеній водоймі традиційним сітковим промислом уже понад 40 років вилучаються особини ляща 3 кращими показниками екстер'єру, що приводить до виживання особин із певним напрямом мінливості, зсуву середнього показника у той чи інший бік. У результаті досліджень встановлено функціональну відповідність морфології умовам навколишнього середовища.

The article considers the long-term resultant action of complex of existing factors on the morphometric indices of the bream (Abramis brama $L$.) in the Kremenchuk reservoir. The breams with the best exterior indices were fished by traditional fishing net during more than $\mathbf{4 0}$ years. This fact resulted in the survival of individuals with certain direction of variability and conduces to the change of an average index to particular value. As a result of the research, functional accordance of the morphometric indices with the environmental conditions was ascertained.

\section{Вступ}

Морфологічні характеристики риб вивчено детальніше, ніж у інших тварин. Це пов’язано із специфікою об'єкта, що вивчається. Спостерігати життя риб у приро-

प

(С) Д. С. Христенко, 2007

Вісник Дніпропетровського університету. Біологія, екологія.

Vìsnik Dnìpropetrovs'kogo unìversitetu. Serîa Bìologiâ, ekologîâ

Visnyk of Dnipropetrovsk University. Biology, ecology.

Vìsn. Dnìpropetr. Unìv. Ser. Bìol. Ekol. 2007. 15(1).

ISSN 2310-0842 print ISSN 2312-301X online www.ecology.dp.ua 
дних умовах існування досить складно і не завжди можливо, тому на допомогу приходить вивчення самого об'єкта та аналіз навколишнього середовища, у якому він мешкає. Виживання особин із певним напрямом мінливості під дією природного добору та результуючої дії факторів зовнішнього природного середовища викликає зміни розмаху мінливості, зсув середнього показника у той чи інший бік. Організм як єдине ціле складається з різних частин (органів), що виконують ту чи іншу роботу. Порівняння накопичених даних по одному виду в різних умовах існування дозволяє робити висновки про вплив тих чи інших факторів на будову організму $[5 ; 10 ; 12]$.

Лящ (Abramis brama L.) в умовах великих рівнинних водосховищ України став основним промисловим видом. В останні роки його промисловий вилов у Кременчуцькому водосховищі складав понад 36 \% від загального вилову [8; 9]. Промисел безперервно ведеться вже майже 46 років. Для раціонального використання промислового стада ляща Кременчуцького водосховища та попередження зникнення виду 3 іхтіофауни здійснено ряд заходів щодо обмеження експлуатації цього водного живого ресурсу. На зазначеній водоймі промисел в основному ведеться ставними сітками 3 кроком вічка 70-90 мм. Із досліджень інших авторів $[1 ; 7 ; 13]$ відомо, що ставні сітки вибірково вилучають особин із певними показниками екстер'єру. 31995 року досліджень впливу умов існування на показники зовнішніх ознак основних промислових видів риб Кременчуцького водосховища не велось, а ті, що були проведені, залишили багато відкритих питань і суперечностей стосовно виду, що вивчається.

Мета наших досліджень - виявити, чи спостерігаються зміни морфометричних характеристик ляща Кременчуцького водосховища порівняно з річковим періодом. Довгострокова результуюча дія комплексу факторів, що склалися в умовах великого рівнинного водосховища, на морфологію виду, який має тривалий цикл життя (у популяції нараховується близько 20 вікових груп), аналізується вперше.

\section{Матеріал і методи досліджень}

Вихідні іхтіологічні матеріали отримано з уловів ставних контрольних сіток із кроком вічка 30-150 мм, які виставлялися в нижній частині Кременчуцького водосховища у весняно-літній заборонний та літньо-осінній промисловий періоди. Збір та обробку іхтіологічних матеріалів проводили за загальноприйнятими в іхтіології методиками $[2-4 ; 11 ; 14]$. Вимірювання проводили за допомогою штангенциркуля. Похибка вимірювального приладу - 0,1 мм. Усього проаналізовано 203 екземпляри ляща, довжиною 15-59 см, вагою від 0,098-5,400 кг. Для порівняння в роботі використано літературні дані про морфометричні ознаки ляща, які були зареєстровані до залиття Кременчуцького водосховища [6].

\section{Результати та їх обговорення}

Для аналізу екстер'єру риб використовують меристичні та пластичні показники. За ними можна судити про умови існування та вплив комплексу факторів навколишнього середовища на промислове стадо риб. Для аналізу використано такий набір показників, за якими є матеріал для порівняння. При порівнянні меристичних ознак ляща середньої течії Дніпра з сучасними даними, зібраними на Кременчуцькому водосховищі, встановлено єдиний план будови спинного та анального плавців (табл. 1).

Також треба відзначити майже однакову кількість лусок у бічній лінії та зябрових тичинок. Достовірної різниці між цими ознаками не спостерігалось. Однак за показником загальної кількості хребців спостерігається достовірна різниця. 3 літературних даних $[5 ; 10]$ відомо, що ця ознака має діагностичний характер і збільшення даного показника свідчить про посилення гідродинамічних властивостей.

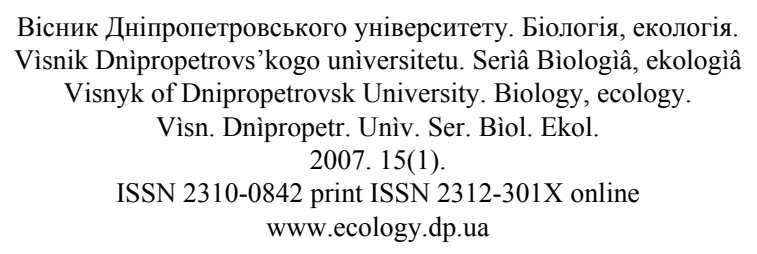


Меристичні показники ляща з середнього Дніпра та Кременчуцького водосховища

\begin{tabular}{|l|c|c|c|}
\hline \multicolumn{1}{|c|}{ Показники } & $\begin{array}{c}\text { p. Дніпро, } \\
M \pm m(n=50[10])\end{array}$ & $\begin{array}{c}\text { Кременчуцьке } \\
\text { водосховище, } M \pm m(n=203)\end{array}$ & $t_{d}$ \\
\hline Розгалужені промені в спинному плавці & 9 & 9 & 0,81 \\
\hline Розгалужені промені в анальному плавці & $25,60 \pm 0,18$ & $25,15 \pm 0,13$ & 0,46 \\
\hline Луски у бічній лінії & $53,36 \pm 0,27$ & $53,68 \pm 0,21$ & 0,90 \\
\hline Зяброві тичинки & $24,30 \pm 0,14$ & $24,86 \pm 0,25$ & 0,22 \\
\hline Загальна кількість хребців & $42,63 \pm 0,21$ & $49,42 \pm 0,19$ & $* * * 3,10$ \\
\hline
\end{tabular}

Примітка: * $-p \leq 0,05 ; * *-p \leq 0,01 ; * * *-p \leq 0,001$.

Із таблиці 2 можна відмітити певні зміни в будові тіла ляща Кременчуцького водосховища. Для родини коропових у 1970-х роках встановлено закономірність, згідно 3 якою серед особин одного й того ж виду, що мешкають в умовах озера або водосховища 3 невеликою швидкістю течії та річок із швидкою течією, найбільш прогонисті будуть річкові, а озерні і водосховищні будуть більш високотілі. Згідно $з$ нашими даними, у ляща 3 дослідженої водойми спостерігається зменшення найбільшої висоти тіла $H$, що вказує на більшу “прогонистість” риб у Кременчуцькому водосховищі порівняно 3 річковим періодом. На фоні цього спостерігається майже повний спектр морфометричних змін, що вказують на поліпшення гідродинамічних властивостей особин ляща, а саме збільшення таких показників, як антедорсальна та постдорсальна відстані, довжина хвостового стебла, загальна кількість хребців. При цьому треба відзначити високу достовірність різниці цих показників (рівень значущості $p$ не менше 0,01 ).

Також відмічено збільшення висоти спинного та анального плавців, що свідчить про збільшення їх ролі як стабілізаторів. Разом із збільшенням довжини грудних плавців цей комплекс змін перебуває у прямій залежності від глибини водойми (точніше - 3 необхідністю проникнення на більшу глибину в пошуках поживи). Це також свідчить про поліпшення гідродинамічних якостей окремих особин у промисловому стаді $[5 ; 10]$. Це суперечить усім наявним на цей час літературним даним, бо прийнято було вважати, що у водосховищах живе лящ, близький до озерної форми.

Всі інші пластичні ознаки істотно не змінились і достовірної різниці між показниками не виявлено.

Таблиия 2

Пластичні показники ляща з середнього Дніпра та Кременчуцького водосховища

\begin{tabular}{|l|c|c|c|}
\hline \multicolumn{1}{|c|}{ Показники**** } & $\begin{array}{c}\text { Середня течія р. Дніпро, } \\
M \pm m(n=30[6])\end{array}$ & $\begin{array}{c}\text { Кременчуцьке водо- } \\
\text { сховище, } M \pm m(n=203)\end{array}$ & $\mathrm{t}_{\mathrm{d}}$ \\
\hline Довжина без хвостового плавця, $l$ & $34,31 \pm 0,20$ & $33,52 \pm 0,75$ & 0,81 \\
\hline Найбільша висота тіла, $H$ & $38,22 \pm 0,32$ & $32,70 \pm 0,27$ & $* * * 7,19$ \\
\hline Антедорсальна відстань, $a D$ & $56,62 \pm 0,31$ & $60,33 \pm 0,29$ & $* * * 4,79$ \\
\hline Постдорсальна відстань, $p D$ & $34,88 \pm 0,20$ & $37,53 \pm 0,34$ & $* * 3,61$ \\
\hline Довжина хвостового стебла, $p l$ & $13,32 \pm 0,15$ & $15,49 \pm 0,37$ & $* * 3,00$ \\
\hline Довжина грудного плавця, $l P$ & $20,15 \pm 0,20$ & $22,03 \pm 0,17$ & $* * 3,09$ \\
\hline Найбільша висота спинного плавця, $h D$ & $24,93 \pm 0,36$ & $27,78 \pm 0,64$ & $* 2,85$ \\
\hline Найбільша висота анального плавця, $h A$ & $18,40 \pm 0,26$ & $20,73 \pm 0,35$ & $* 2,98$ \\
\hline
\end{tabular}

Примітка: * $-p \leq 0,05 ; * *-p \leq 0,01 ; * * *-p \leq 0,001 ; * * * *$ - довжина без хвостового плавця $(l)$ наведена у см, а всі інші характеристики - у відсотках до довжини тіла $l$.

За результатами наших даних можна зробити висновок, що за 46 років промислового використання Кременчуцького водосховища фактори зовнішнього середовища, що склалися у цій акваторії, значно вплинули на екстер'єр особин ляща. Вагоме місце у цьому впливі належить сітковому промислу. За літературними даними, ставними сіт-

Вісник Дніпропетровського університету. Біологія, екологія.

Vìsnik Dnìpropetrovs'kogo unìversitetu. Serìa Bìologîa, ekologîâ Visnyk of Dnipropetrovsk University. Biology, ecology. Vìsn. Dnìpropetr. Unìv. Ser. Bìol. Ekol. 2007. 15(1).

ISSN 2310-0842 print ISSN 2312-301X online www.ecology.dp.ua 
ками упродовж цього періоду вибірково виловлювались більш високотілі особини, що мають кращий товарний вигляд [8; 9; 13]. Цей постійний відбір із популяції призвів до накопичення у стаді нетипових низькотілих і більш видовжених особин. Крім того, лящ, як типовий бентофаг, вимушений робити більші щоденні харчові міграції у товщі води, що спричинено збільшенням нагульних площ після залиття водосховища.

\section{Висновки}

Лящ за 46 років існування в Кременчуцькому водосховищі значно поліпшив свої гідродинамічні властивості і за набором морфометричних показників наблизився до річкової форми. Ставними сітками вибірково виловлювались більш високотілі особини, що призвело до накопичення в стаді нетипових низькотілих і більш видовжених особин. 3 метою оптимізації промислового навантаження та розробки науково обгрунтованого використання популяції ляща необхідно провести дослідження щодо відповідності існуючої промислової міри мінімально дозволеному кроку вічка крупновічкових сіток.

\section{Бібліографічні посилання}

1. Денисов Л. И. Рыболовство на водохранилищах. - М.: Пищевая промышленность, 1978. $-288 \mathrm{c}$.

2. Методи гідроекологічних досліджень поверхневих вод / За ред. В. Д. Романенка. - К.: Логос, 2006. - 406 c.

3. Методика збору і обробки іхтіологічних і гідробіологічних матеріалів з метою визначення лімітів промислового вилучення риб з великих водосховищ і лиманів України: № 166. Затв. наказом Держкомрибгоспу України 15.12.1998. - К., 1998. - 47 с.

4. Мина М. В. О возможностях использования в морфометрических исследованиях рыб оценок признаков, полученных разными операторами / М. В. Мина, Б. А. Лёвин, А. Н. Мироновский // Вопросы ихтиологии. - 2005. - Т. 45, № 3. - С. 331-341.

5. Митрофанов В. П. Экологические основы морфометрического анализа рыб. - Алма-Ата: КазГУ, 1977. -35 c.

6. Мовчан Ю. І. Фауна України. Риби / Ю. І. Мовчан, А. І. Смирнов. - Т. 8, вип. 2. - К.: Наукова думка, 1983. - С. 71-105.

7. Никольский Г. В. Теория динамики стада рыб. - М.: Пищевая пром-сть, 1974. - 446 с.

8. Озинковская С. П. Рыбохозяйственное изучение водохранилищ Днепровского каскада // Рибне господарство. - 2000. - Вип. 56-57. - С. 155-162.

9. Озінковська С. П. Оцінка динаміки і структури популяції ляща Кременчуцького водосховища / С. П. Озінковська, В. І. Полторацька, В. Ц. Головко // Рибне господарство. 2001. - Вип. 59-60. - С. 86-97.

10. Подобайло А. В. Мінливість морфологічних та характеристика морфофізіологічних ознак деяких туводних риб басейну Кременчуцького водосховища: Дис. ... канд. біол. наук: 03.00.02. - К., 1995. - $168 \mathrm{c}$.

11. Правдин И. Ф. Руководство по изучению рыб (преимущественно пресноводных). - М.: Пищевая промышленность, 1966. - 376 с.

12. Романенко В. Д. Основи гидроекології. - К.: Генеза, 2004. - 664 с.

13. Цибульник О. А. Порівняльна характеристика популяцій ляща Київського та Кременчуцького водосховищ // Рибне господарство. - 2000. - Вип. 58. - С. 72-75.

14. Methods for fish biology / Ed. C. B. Schreck, P. B. Moyle. - Bethesda, Maryland, USA, 1990. $685 \mathrm{p}$.

Надійшла до редколегії 10.12.2006

Вісник Дніпропетровського університету. Біологія, екологія.

Vìsnik Dnìpropetrovs'kogo unìversitetu. Serìa Bìologîa, ekologîâ Visnyk of Dnipropetrovsk University. Biology, ecology. Vìsn. Dnìpropetr. Unìv. Ser. Bìol. Ekol. 2007. 15(1).

ISSN 2310-0842 print ISSN 2312-301X online www.ecology.dp.ua 